\title{
PERAN GURU PAK SEBAGAI MOTIVATOR
}

\author{
Yowenus Wenda* \\ Sekolah Tinggi Teologi Gereja Injili di Indonesia (STT GIDI) Papua \\ Program Studi Pendidikan Agama Kristen \\ E-mail:yoellwenda@gmail.com
}

\begin{abstract}
Abstrak:
Keberhasilan pelaksanaan kegiatan proses belajar mengajar sangat tergatung pada guru PAK karena guru merupakan ujung tombak dalam pembelajaran. Guru PAK adalah pendidik yang menjadi tokoh panutan. Oleh sebab itu, tugas dan tanggung jawab guru PAK adalah membantu peserta didik agar dapat mengembangkan potensi yang dimilikinya secara maksimal. Potensi peserta didik yang harus dikembangkan bukan saja menyangkut masalah kogniti (kecerdasan) dan psikomotorik (keterampilan), melainkan seluruh aspek kepribadiannya. Guru PAK tidak hanya dituntut untuk memiliki pengetahuan atau kemampuan dalam bidang belajar dan pembelajaran tetapi juga dalam memotivasi peserta didik. Guru PAK berperan dalam mengajarkan nilai- nilai moral dan memotivasi peserta didik. Guru PAK perlu memahami konsep-konsep motivasi sehingga dapat berfungsi sebagai fasilitator bagi perkembagan peserta didik.
\end{abstract}

Kata Kunci : Peran, Guru PAK, Motivator

\section{A. Pendahuluan}

Guru Pendidikan Agama Kristen sebagai bagian tujuan pendidikan nasional yang telah, sedang bahkan akan mempersiapkan peserta didik secara khusus dalam proses Pendidikan Agama Kristen dapat meningkatkan motivasi kepada peserta didik menyangkut seluruh aspek kehidupan, yakni aspek fisik, psikologis, intelektual, sosial, dan mental/spiritual.

Pembahan dalam tulisan ini difokuskan pada peran guru Pendidikan Agama Kristen sebagai motivator dalam meningkatkan meningkatkan motivasi belajar peserta didik, merangsang dan memberikan dorongan, mengembangkan potensi yang dimiliki peserta didik, sehingga menumbuhkan kepercayaan diri dan memahami tujuan hidup yang harus dicapai peserta didik. 


\section{B. Pembahasan}

\section{Guru Pendidikan Agama Kristen}

Dalam dunia pendidikan guru merupakan faktor penting dan utama, sebab guru adalah orang yang bertanggung jawab terhadap perkembangan jasmani dan rohani peserta didik. Berdasarkan UU RI NO 14 TAHUN2005 Guru adalah pendidik profesional dengan tugas utama mendidik,mengajar,membimbing, mengarahkan, melatih, menilai, dan mengevaluasi peserta didik pada pendidikan anak usia dini jalur pendidikan formal, pendidikan dasar, dan pendidikan menengah. ${ }^{1}$ Selanjutnya H. Martinis Yamin berpendapat bahwa gelar yang melekat pada guru adalah seorang "pahlawan tanpa tanda jasa”, gelar ini tidak semua guru yang dapat menerimanya, karena gelar ini merupakan suatu penghormatan yang berat disandang, secara logika tentu bertanya, apakah ada seorang pahlawan yang pakai tanda jasa? Sedangkan guru adalah seorang professional, artinya guru penyedia jasa, akan tetapi jasa guru tidak dapat diakui, apakah mungkin seseorang dapat berbuat sesuatu secara maksimal tanpa pernah tahu menahu dengan kebutuhan hidupnya, rasanya tidak mungkin hal itu terjadi. ${ }^{2}$ Aka itu, guru boleh saja rela dalam mengembang tugas mengajar akan tetapi guru perlu memikirkan kesejajahteraan keluarganya.

Sedanggkan Kamus Besar Bahasa Indonesia dalam Martin Yamin pahlawan adalah oarang yang gagah berani atau terkemuka. Artinya seorang pejuang dalam memperjuangkan negaranya dari penjajah dan ikut memperjuangkan kemerdekaan,

\footnotetext{
${ }^{1}$ Undang - undang RI No 14 tahun 2005

${ }^{2}$ H. Martinis Yamin, Profesionalisme Guru \& Implementasi KTSP dilengkapi dengan UU No. 14 Tahun 2005 tentang Guru dan Dosen, (Jakarta: Gaung Persada Press, 2007) hal. 53
} 
jika ia meninggal dalam pertempuran, maka pejuang tersebut dapat dikatakan pahlawan, sedangkan perjuangan yang dilakukan guru adalah memerangi kebodohan, bukan dalam pertempuran secara fisik yang dilakukan pejuang merebut kemerdekaan, akan tetapi pejuang dalam memerangi kebodohan. Sesuai dengan pendapat di atas, guru merupakan orang pertama yang mencerdaskan manusia, karena gurulah memberi bekal pengetahuan, pengalaman, megembangkan nilai-nilai moran dan keimanan terhadap peserta didik. Ada sebuah kalimat yang sangat menarik adalah guru bisa melahirkan orang-orang terhebat di dunia ini, tetapi orang-orang terhebet di dunia ini tidak akan bisa melahirkan guru.

Secara spesifik, istilah guru Kristen dapat diketahui tiga hal penting yaitu: (1) guru dalam perspektif Kristen, artinya penjelasan menyangkut pembahasan umum tentang guru serta seluk beluk keguruan dari sudut pandang iman Kristen, (2) guru yang Kristen, berarti berkaitan dengan identitas atau jati diri serta peran guru PAK sebagai orang Kristen dan (3) guru PAK yang hanya memberi pengajaran yang berkaitan dengan iman Kristen di lembaga formal maupun non formal. Misalnya: di gereja, sekolah dan panti asuhan. Sedangkan poin terakhir ini dapat dijelaskan tentang "guru yang mengajarkan iman Kristen" memberi kesan lebih sempit tentang lingkup tugasnya.

Menurut Boehlke guru PAK adalah seorang penganjar, pengalaman belajar yang siap memanfaatkan berbagai sumber buku, peralatan, peryataan, objek dan sebagainya guna menolong orang lain bertumbuh dalam pengetahuan iman Kristen dan pengalaman percaya secara pribadi". ${ }^{3}$ Sedangkan Khoe Yao Tung berpendapat bahwa guru PAK haruslah orang yang terpanggil dalam kasih Anugerah Tuhan karena

${ }^{3}$ Boehlke, Robert R., Sejarah Perkembangan Pikiran dan Praktek Pendidikan Agama Kristen dari Plato sampai IG Loyoha, (Jakarta: BPK Gunung Mulia, 2000) hal.698 
panggilan pelayanan dalam ladang Tuhan sudah merupakan bagian dari panggilan kehidupannya. ${ }^{4}$

Sesuai dengan uraian di atas, dapat disimpulakan bahwa guru Pendidikan Agama Kristen adalah pendidik yang menjadi tokoh panutan dan identifikasi bagi peserta didik. Tugas seorang guru PAK adalah menuntun peserta didik berpindah dari satu tahap kehidupan pada tahapan berikutnya atau kata lain keluar dari kegelapan ke dalam terang, serta lepas dari kebodohan dan beralih pada kehidupan yang cerdas. Sebab gurulah yang menentukan dasar atau pondasi bagi pengembangan kepribadian peserta didik atas campur tangan kuasa Tuhan. Selain menuntun, guru PAK bertanggung jawab membantu peserta didik agar dapat mengembangkan potensi yang dimilikinya secara maksimal. Potensi peserta didik yang harus dikembangkan bukan hanya menyangkut masalah koknitif atau kecerdasan dan keterampilan (skill), melainkan menyangkut seluruh aspek kepribadian. Sehubungan dengan hal tersebut, guru tidak hanya dituntut untuk memiliki pemahaman atau kemampuan dalam bidang belajar dan pembelajaran tetapi juga dalam memberi motivasi, dorongan untuk mencapai tujuan yang diharapkan terutama bagi peserta didik yang mengalami patah semangat, keputusasaan, kegagalan, peran guru PAK sebagai motivator sangat diperlukan agar peserta didik tersebut dapat dibangkitkan kembali.

Berkaitan dengan kompetensi yang dimiliki seorang guru Pendidikan Agama Kristen dalam mengajarkan nilai-nilai moral dan keimanan Kristiani, guru PAK memiliki peran yang sangat strategis sebagai motivator bagi peserta didiknya karena berkaitan dengan pendekatan secara psikologis terhadap peserta didik. Oleh sebab itu, hendaknya guru PAK memahami konsep-konsep dalam memberi dorongan dan motivasi sehingga diharapkan mampu berfungsi.

${ }^{4}$ Khoe Yao Tung, Terpanggil Menjadi Pendidik Kristen yang Berhati Gembala Mempersiapkan Sekolah dan Pendidik Kristen Menghadapi Tantangan Global pada masa Kini, (Yogyakarta: Andi Offset, 2006) hal. 120 


\section{Pengertian Pendidikan Agama Kristen}

Istilah Pendidikan Agama Kristen sebenarnya berasal dari Bahasa inggris Christian Education. Dalam bahasa Indonesia diterjemahkan sebagai" Pendidikan Agama Kristen". Menurut Werner C. Graendorf Pendidikan Agama Kristen adalah proses pengajaran dan pembelajaran yang berdasarkan pada Alkitab, berpusatkan pada Kristus dan bergantung pada kuasa Roh Kudus yang membimbing setiap pribadi. Dalam kitab Perjanjian Lama (PL) Pendidikan Agama Kristen adalah pendidikan yang tidak berkesudahan atau yang berlangsung seumur hidup dan yang terus-menerus diulang-ulang, sebagaimana perintah Tuhan dalam Ulangan 6:7.

Pendidikan Agama Kristen adalah suatu usaha untuk membentuk dan membimbing peserta didik tumbuh dan berkembang mencapai kepribadian yang utuh mencerminkan manusia sebagai gambar Allah yang memiliki kasih dan ketaatan kepada Tuhan, kecerdasan, keterampilan, budi pekerti luhur, kesadaran untuk memelihara dan melestarikan lingkungan hidup, bertanggung jawab dalam pembangunan masyarakat, bangsa, dan negara.

Pendidikan Agama Kristen adalah suatu usaha pendidikan. Oleh karena itu, ia merupakan usaha yang sadar, sistematis, dan berkesinambungan, apa pun bentuknya. Ini tidak berarti bahwa pendidikan hanya terbatas pada pendidikan formal baik di sekolah atau di dalam gereja, melainkan juga pendidikan yang dilakukan dengan pendekatan sosialisasi yang disengaja. ${ }^{5}$

Sedangkan Homrighousen mengatakan bahwa hakikat pendidikan agama Kristen sebenarnya memuat dua hal pokok yaitu aspek pengajaran dan pengalaman yang menjadi satu kesatuan. Aspek pengajaran meliputi pengetahuan yang diberikan oleh pendidik berupa teori pokok iman Kristen. Aspek pengajaran ini untuk membangun

${ }^{5}$ Daniel Nuhamara. Pembimbing Pendidikan Agama Kkristen. (Bandung: Jurnal Info Media, 2009) hal. 
kepercayaan Kristen dalam diri peserta didik. Aspek pengalaman meliputi praktik atas teori pengajaran yang telah diterima.

Dengan demikian dari beberapa pandangan PAK di atas, dapat disimpulkan bahwa PAK adalah usaha mendidik serta mengajar berdasarkan firman Allah kepada peserta didik yang disesuikan dengan kebutuhan hidup agar dapat memahami dan menghayati nilai-nilai Kristiani serta mengaplikasikannya dalam kehidupan keseharian baik melalui kata-kata, sikap, dan perilaku.

Tujuan PAK adalah Amanat Tuhan Yesus. "karena itu pergilah, jadikanlah semua bangsa murid-Ku dan baptislah mereka dalam nama Bapa dan Anak dan Roh Kudus, dan ajarlah mereka melakukan segala sesuatu yang telah Kuperintahkan kepadamu. Dan ketahuilah, Aku menyertai kamu senantiasa sampai kepada akhir zaman” (Mat. 28:19-20).

\section{Peran Guru PAK sebagai Motivator}

\section{a. Peran}

Kata peran dalam kamus oxford dictionary diartikan sebagai tugas seseorang atau fungsi. ${ }^{6}$ Sedangkan istilah peran dalam Kamus Besar Bahasa Indonesia mempunyai arti pemain sandiwara (film), tukang lawak pada permainan makyong, perangkat tingkah yang diharapkan dimiliki oleh orang yang berkedudukan dimasyarakat. ${ }^{7}$ Istilah peran jika di gunakan dalam lingkungan pekerjaan, maka seseorang yang diberi (atau

\footnotetext{
${ }^{6}$ The NewOxford Illustrated Dictionary, Oxford University, Loc. Cit, hal.1466

${ }^{7}$ Purwadarminta, Kamus Besar Bahasa Indonesia, (Jakarta : Balai Pustaka, 2005) hal.
} 
mendapatkan) sesuatu posisi, juga diharapkan menjalankan perannya sesuai dengan apa yang diharapkan oleh pemberi pekerjaan tersebut.

"Guru memiliki andil yang sangat besar terhadap keberhasilan pembelajaran di sekolah, guru sangat berperan dalam membantu perkembangan peserta didik untuk mewujudkan tujuan hidupnya secara optimal. Keyakinan ini muncul karena manusia adalah mahluk lemah, yang dalam perkembangannya senantiasa membutuhkan orang lain, sejak lahir, bahkan sampai saat meninggal. Semua itu menunjukkan bahwa setiap orang membutuhkan orang lain dalam perkembangannya, demikian halnya dengan peserta didik. Minat,bakat, kemampuan dan potensi-potensi yang dimiliki oleh peserta didik tidak akan berkembang secara optimal tanpa bantuan guru. ${ }^{18}$ Guru adalah faktor penentu bagi keberhasilan pendidikan disekolah, karena guru merupakan sentral serta sumber kegiatan belajar mengajar.

Sesuai dengan uraian di atas, peran guru Pendidikan Agama Kristen (PAK) tidak hanya mengajar, mendidik dan melatih, karena pada dasarnya pembelajaran Agama Kristen merupakan upaya untuk mengarahkan peserta didik ke dalam proses belajar sehingga peserta didik dapat memperoleh tujuan belajar sesuai dengan apa yang diharapkan. Oleh sebab itu, pembelajaran hendaknya memperhatikan kondisi individu atau peserta didik karena merekalah yang akan belajar.

\section{b. Motivator}

Motivator adalah seseorang yang memberikan motivasi atau semangat baik kepada individu, organisasi, dengan tujuan dapat meningkatkan semangat dan kualitas hidup. Menurut Wikipedia motivator adalah orang yang memiliki profesi atau pencaharian dari memberikan motivasi kepada orang lain. Selanjutnya orang (perangsang) yang menyebabkan timbulnya motivasi pada orang lain untuk

${ }^{8}$ Mulyasa, E, Menjadi Guru Profesional, (Bandung, PT.Remaja Rosdakarya, 2009). hal.35 
melaksanakan sesuatu; pendorong; penggerak. ${ }^{29}$ Berkaitannya dengan pembelajaran, guru PAK sebagai seorang motivator tidak mudah, ia harus tahu bagaimana menarik simpati peserta didik dengan kata-katanya. Dalam kegiatan proses belajar mengajar, motivasi dapat dikatakan sebagai keseluruhan daya penggerak di dalam diri peserta didik yang menimbulkan dan menjamin kelangsungan serta memberikan arah kegiatan belajar, sehingga diharapkan tujuan atau target dapat tercapai.

Berdasarkan uraian di atas, guru Pendidikan Agama Kristen dapat merangsang dan memberikan dorongan motivasi serta mengembangkan potensi yang dimiliki peserta didik, menumbuhkan swadaya (aktivitas) dan daya cipta (kreativitas), sehingga akan terjadi dinamika dalam proses belajar mengajar, sehingga memperoleh hasil belajar yang optimal.

\section{c. Motivasi}

Kata motiv di artikan sebagai daya upaya yang mendorong seseorang untuk melakukan sesuatu. Sedangkan motif dapat dikatakan sebagai daya penggerak dari dalam dan di dalam subjek untuk melakukan aktifitas-aktifitas tertentu demi mencapai suatu tujuan. ${ }^{10}$ Secara etimologi kata motivasi berasal dari kata motif yang berarti segala sesuatu yang mendorong seseorang untuk bertindak melakukan sesuatu. Istilah motivasi berasal dari bahasa Latin movere yang bermakna 'bergerak', istilah ini bermakna mendorong, mengarahkan tingkah laku manusia.

Motivasi adalah proses yang memberi semangat, arah, dan kegigihan perilaku. Artinya, perilaku yang memotivasi adalah perilaku yang penuh energy, terarah dan bertahan lama. ${ }^{11}$ Sedangkan Oemar Hamalik menjelaskan bahwa motivasi untuk ingin berprestasi merupakan motivasi yang terpenting. motivasis adalah dorongan yang

${ }^{9}$ https://id.wikipedia.org/wiki/Motivator, diakse pada 29 November 2018.

${ }^{10}$ Yowenus Wenda, Psikologi Pendidikan, (Yogyakarta: illumination Publishing, 2012) hal. 48

${ }^{11}$ Yowenus Wenda, Belajar dan Pembelajaran, (Yogyakarta: illumination Publishing, 2012) hal. 21 
menyebabkan terjadinya suatu perbuatan atau tindakan tertentu. Perbuatan belajar terjadi karena adanya motivasi yang mendorong seseorang untuk melakukan perbuatan belajar. $^{12}$ Motivasi mengandung tiga komponen pokok yaitu: (1) menggerakkan, (2) mengarahkan dan (3) menopang tingkah laku manusia.

Untuk itu motivasi sangat diperlukan, sebab peserta didik yang tidak mempunyai motivasi dalam belajar, tidak akan mungkin dapat melakukan aktivitas belajar. Proses pembelajaran akan berhasil, jika peserta didik mempunyai motivasi yang tinggi dalam belajar. Motivasi dapat dibagi menjadi dua macam yaitu:

1. Internal; motivasi yang timbul dari dalam diri individu sendiri tanpa ada paksaan dorongan dari orang lain, tetapi atas dasar kemauan sendiri

2. Eksternal; motivasi yang timbul sebagai akibat pengaruh dari luar individu, apakah karena adanya ajakan, suruhan, atau paksaan dari orang lain sehingga dengan keadaan demikian peserta didik mau melakukan belajar.

Berdasarkan uraian di atas, dapat diketahui bahwa motivasi terjadi apabila peserta didik mempunyai keinginan dan kemauan untuk melakukan suatu kegiatan atau tindakan dalam rangka mencapai tujuan tertentu.

\section{Aplikasi Peran Guru PAK dalam Pembelajaran}

Pembelajaran pada dasarnya merupakan pemberian stimulus kepada peserta didik agar terjadi respons yang positif pada diri peserta didik. Kesediaan dan kesiapan peserta didik dalam mengikuti proses belajar mengajar Pendidikan Agama Kristen akan mampu menimbulkan respons yang baik terhadap stimulus yang peserta didik terima dalam pembelajaran. Respons akan menjadi kuat, jika stimulusnya juga kuat. Hubungan antara stimulus dan respons akan menjadi lebih baik bila dapat menghasilkan hal-hal yang menyenangkan. Stimulus yang dimaksud disini adalah apa

12 Ibid 
saja yang guru PAK berikan kepada peserta didik seperti dorongan, motivasi dan semangat. Sedangkan respon adalah tanggapan atau balasan terhadap apa saja yang diberikan oleh guru PAK kepada peserta didik. Berikut ini adalah hasil dari stimulu dan respon.

$\square$ Peserta didik akan lebih termotivasi untuk belajar walaupun ia tidak diawasi oleh guru Pendidika Agama Kristen.

$\square$ Menghasilkan peserta didik yang berkepribadian, pintar, cerdas, aktif,mandiri, tidak bergantung kepada guru Pendidikan Agama Kristen melainkan kepada dirinya sendiri.

$\square$ Peseta didik mampu bersaing atau berkompetisi dan memiliki kemampuan komunikasi yang lebih baik.

$\square$ Peserta didik mampu berpikir rasional, menemukan masalah, dan memecahkan masalah yang peserta didik hadapi.

$\square$ Semangat peserta didik semakin meningkat dalam mencapai tujuan yang dicatacitakan atau yang diharapkan.

\section{Kesimpulan}

Guru Pendidikan Agama Kristen memiliki peran sebagai motivator karena dalam hal ini berkait dengan tugas dan tanggung jawabnya untuk mengembangkan nilai-nilai moral dan keimanan Kristiani kepada peserta didik. Nilai-nilai nilai-nilai moral dan keimanan Kristiani ini merupakan landasan bagi peserta didik dalam membentuk sikap, moral dan karakter peserta didik sesuai dengan ajaran firman Tuhan.

Guru Pendidikan Agama Kristen sebagai motivator tentunya akan lebih mudah untuk masuk dalam ranah permasalahan dan pergumulan peserta didik karena secara psikologis guru PAK dapat melakukan pendekan melalui konsep-konsep nilai-nilai moral dan keimanan Kristiani sehingga dapat membangkitkan gairah, dan 
meningkatkan motivasi peserta didik dan memiliki nilai-nilai moral dan keimanan Kristiani.

Guru PAK dapat membantu peserta didik agar mampu memahami dan memanfaatkan potensi yang ada pada diri peserta didik secara optimal agar memiliki rasa percaya diri dan memiliki keberanian dalam membuat keputusan. 


\section{DAFTAR PUSTAKA}

Boehlke, Robert R., Sejarah Perkembangan Pikiran dan Praktek Pendidikan Agama Kristen dari Plato sampai IG Loyoha, Jakarta: BPK Gunung Mulia, 2000.

Daniel Nuhamara. Pembimbing Pendidikan Agama Kkristen. Bandung: Jurnal Info Media, 2009.

H. Martinis Yamin, Profesionalisme Guru \& Implementasi KTSP dilengkapi dengan UU No. 14 Tahun 2005 tentang Guru dan Dosen, Jakarta: Gaung Persada Press, 2007.

Khoe Yao Tung, Terpanggil Menjadi Pendidik Kristen yang Berhati Gembala Mempersiapan Sekolah dan Pendidik Kristen Menghadapi Tantangan Global pada masa Kini, (Yogyakarta: Andi Offset, 2006.

Purwadarminta, Kamus Besar Bahasa Indonesia. Jakarta : Balai Pustaka, 2005.

Mulyasa, E, Menjadi Guru Profesional. Bandung, PT.Remaja Rosdakarya, 2009.

Undang - undang RI No 14 tahun 2005.

Yowenus Wenda, Psikologi Pendidikan. Yogyakarta: illumination Publishing, 2012. , Belajar dan Pembelajaran, (Yogyakarta: illumination Publishing,

2012. https://id.wikipedia.org/wiki/Motivator, diakse pada 29 November 2018. 


\section{Biografi:}

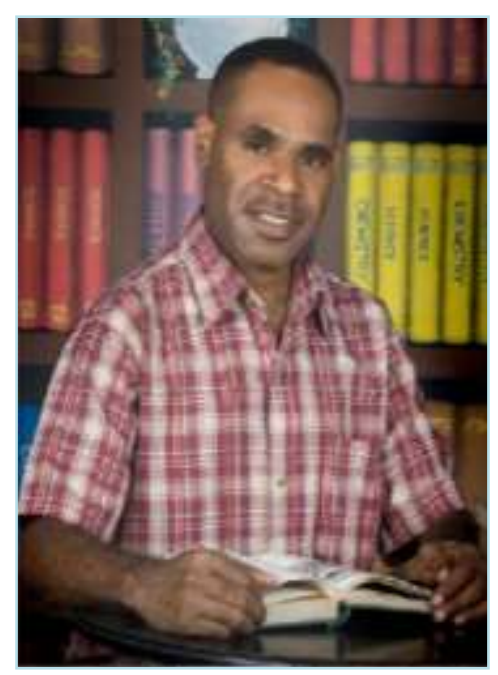

Yowenus Wenda, S.Pd.K., M.Pd., lahir 12 Desember 1983 di Bagoni, distrik Gilobandu, Kab. Tolikara-Papua. Tahun 2009 penulis menyelesaikan pendidikan jenjang S1 di Universitas Kristen Surakarta (UKS) Jawa Tengah pada Program Studi Pendidikan Agama Kristen (PAK). Kemudian tahun 2013 menyelesaikan pendidikan jenjang S2 di Universitas Negeri Yogyakarta pada Program Studi Teknologi Pembelajaran (TP). Pendidikan jenjang Doktor (S3) sedang menyelesaikan Disertasi di Sekolah Tinggi Agama Kristen Protestan Negeri (STAKPN)

Papua pada Program Studi Pendidikan Agama Kristen (PAK). Pada 17 Agustus 2013 penulis menikah dengan

Mella Chettriana Pattinasarane, M.Th dan dikarunia 2 orang putra yakni; Yoelton Michael Wenda dan Yomilton Junior Gabriel Wenda.

Mengawali Karir : Tahun 2003-2006 aktif melayani di GPII Eben Haezer Yogyakarta, tahun 2006 - 2013 aktif melayani di GIDI Syalom Solo Jawa Tengah, Tahhun 2011-2013 mengabdi sebagai dosen di Sekolah Tinggi Teologi Nazareene (STTNI) Yoyakarta dan Universitas Kristen Surakarta (UKS) Solo Jawa Tengah, tahun 2011 - sekarang sebagai Wakil Direktur Penerbit illumiNation Publishing Yogyakarta. Sejak tahun 2014 penulis diangkat menjadi dosen tetap di STT GIDI-Papua. Tahun 2014sekarang dipercayakan sebagai Kepala Laboratorium Komputer, Kepala Pangkalan Data DIKTI dan tahun 2015 - sekrang ketua Program Studi Pendidikan Agama Kristen (PAK). Disamping kesibukan kampus aktif mmenulis buku-buku Pendidikan. Penulis memiliki kompetensi Pendidikan Agama Kristen dan Teknologi Pembelajaran. Email:yoelwenda@yahoo.co.id;

yoellwenda@gmail.com;www.yoelwenda.blogspot.com;

www.yowenuswenda.blogspot.com 